\title{
Tyrphostin AG 879
}

National Cancer Institute

\section{Source}

National Cancer Institute. Tyrphostin A G 879. NCI Thesaurus. Code C1491.

A compound that selectively inhibits protein tyrosine kinase and nerve growth factordependent tyrosine phosphorylation. $(\mathrm{NCl})$ 